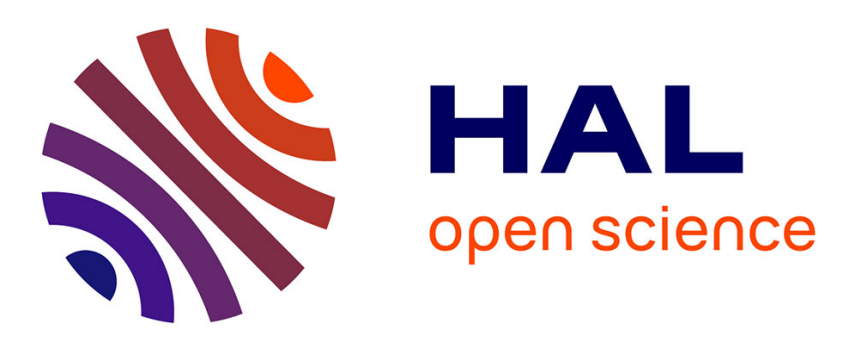

\title{
Pollination ecology and floral scent chemistry of Philodendron fragrantissimum (Araceae)
}

Marc Gibernau, Artur Campos D. Maia, Daniela Maria Do Amaral Navarro

\section{To cite this version:}

Marc Gibernau, Artur Campos D. Maia, Daniela Maria Do Amaral Navarro. Pollination ecology and floral scent chemistry of Philodendron fragrantissimum (Araceae). Botany Letters, 2021, pp.1-11. 10.1080/23818107.2021.1909497 . hal-03262110

\section{HAL Id: hal-03262110 https://hal.science/hal-03262110}

Submitted on 16 Jun 2021

HAL is a multi-disciplinary open access archive for the deposit and dissemination of scientific research documents, whether they are published or not. The documents may come from teaching and research institutions in France or abroad, or from public or private research centers.
L'archive ouverte pluridisciplinaire HAL, est destinée au dépôt et à la diffusion de documents scientifiques de niveau recherche, publiés ou non, émanant des établissements d'enseignement et de recherche français ou étrangers, des laboratoires publics ou privés. 


\title{
Pollination ecology and floral scent chemistry of Philodendron fragrantissimum (Araceae)
}

\author{
Marc Gibernau $^{\mathrm{a}}$, Artur Campos D. Maia ${ }^{\mathrm{b}}$ and Daniela Maria do Amaral Navarro ${ }^{\mathrm{c}}$
}

${ }^{\mathrm{a} C N R S}$ - University of Corsica, UMR 6134 SPE, Laboratory of Sciences for the Environment, Vignola, Route des Sanguinaires, 20000 Ajaccio, France; 'bederal University of Paraíba, Department of Systematics and Ecology, Cidade Universitária s/n, 58051-900 João Pessoa,

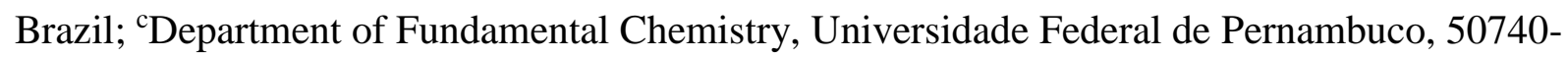
560, Recife, Brazil

CONTACT Marc Gibernau; gibernau_m@univ-corse.fr ; CNRS - University of Corsica, UMR 6134 SPE, Laboratory of Sciences for the Environment, Vignola, Route des Sanguinaires, 20000 Ajaccio, France

\begin{abstract}
In French Guiana, Philodendron fragrantissimum (Hook.) G.Don was specifically pollinated by a single species of night-active cyclocephaline scarab, Cyclocephala simulatrix Höhne. Its inflorescences exhibited short-lasting anthesis $(\sim 30 \mathrm{~h})$ and characteristic floral traits such as floral thermogenesis, edible/nutritious floral tissues, and profuse floral scent emission. Our insect exclusion experiments indicate that entomophilous cross-pollination is obligatory for P. fragrantissimum, with olfactory signalling playing a pivotal role in pollinator attraction. Three volatile organic compounds - methyl benzoate, $(Z)$-jasmone, and dehydrojasmone -
\end{abstract}


dominate the floral scent of pistillate phase inflorescences (84-99\%), but their relative proportions were different according to the headspace sampling method used, dynamic or static. Local pollination services provided by both female and male $C$. simulatrix are effective, as evidenced by a high visitation rate $(>70 \%)$ that resulted in $55 \%$ of the inflorescences maturing into infructescences. Moreover, pollination was highly efficient, since 2 - 3 beetles sufficed to pollinate an average $94 \%$ of the pistillate flowers.

KEYWORDS: Cyclocephala, thermogenesis, reproductive success, volatile organic compounds, headspace sampling. 


\section{Introduction}

Among the angiosperm families with beetle-pollinated species (cantharophilous), Araceae represents one of the most diverse in the Neotropics with an estimated 800 species associated with cyclocephaline scarabs (Melolonthidae, Dynastinae, Cyclocephalini) alone. Although these highly specialized scent-oriented pollinators have been documented in association with the inflorescences of Caladium Ventenat (Maia and Schlindwein 2006), Dieffenbachia Schott (Valerio 1984; Young 1986, 1990; Cuartas-Hernandez 2006; Gibernau 2015a, 2015b), Gearum N.E. Brown (Gonçalves and Maia 2006), Montrichardia H. Crüger (Gibernau et al. 2003), Syngonium Schott (Beath 1998), Taccarum Brongniart ex Schott (Maia et al. 2013), and Xanthosoma Schott (Garcia-Robledo et al. 2004; Gottsberger et al. 2020), it is the megadiverse genus Philodendron Schott with ca. 490 species that draws most attention to the diversity of such plant-pollinator interactions (Boyce and Croat 2020). All the studies on the pollination of Philodendron have demonstrated that pollination occurs at dusk or early evening and exclusively by cyclocephaline scarabs (Gottsberger and Amaral 1984; Gottsberger and Silberbauer-Gottsberger 1991; Gibernau et al. 1999, 2000; Gibernau and Barabé 2002; Seymour et al. 2009; Maia et al. 2010; Gottsberger et al. 2013; Moore and Jameson 2013; Pereira et al. 2014; Maldonado et al. 2015; Moore et al. 2018; Gonçalves-Souza et al. 2017, 2018; Barbosa et al. 2019; Dupuis and Perrin 2020). We can enumerate four defining floral traits correlated with the pollination of Philodendron spp., as well as with that of other angiosperm taxa associated with flower-visiting cyclocephaline scarabs: i) crepuscular/nocturnal anthesis, ii) nocturnal floral thermogenesis, iii) abundant edible floral tissues and pollen, and iv) profuse floral scent emission (Gonçalves and Maia 2006; Gottsberger et al. 2012; Maia et al. 2012; Moore and Jameson 2013; Teichert et al. 2018). 
The inflorescence of Philodendron is composed of a spathe, which is a modified bract surrounding/wrapping an unbranched spike bearing minute unisexual flowers, called the spadix (Barabé and Gibernau 2015). The spadix is known to undergo floral thermogenesis through a non-oxidative respiration process in which the mitochondrial electrochemical potential is dissipated by heat through an alternative uncoupling protein (Ito and Seymour 2005). The thermogenic pattern is synchronized with the anthesis and pollination events coinciding with both the scented pollinator attraction phase (i.e. stigma receptivity) and the pollinator departure time (i.e. pollen dehiscence). The spadix commonly warms up more than $10{ }^{\circ} \mathrm{C}$ (range $3-22{ }^{\circ} \mathrm{C}$ ) above ambient air temperature (Gibernau et al. 1999, 2000; Seymour 1999; Gibernau and Barabé 2000, 2002; Barabé et al. 2002; Gibernau et al. 2005; Seymour and Gibernau 2008; Maia et al. 2010; Seymour 2010; Gottsberger et al. 2013; Pereira et al. 2014; Barbosa et al. 2019). Aside from aiding the volatilization of attractive floral scent compounds and pollen release, the heat generated by floral thermogenesis functions as an energy-saving boost for endothermic cyclocephaline scarabs, and many species pollinated by these insects remain thermogenically active all through the night, thus increasing beetle activity (Seymour et al. 2009).

Flower visiting cyclocephaline scarabs have a keen detection of scent, as they are often seen in a 'honing-in' flight pattern towards fragrant sources (Gottsberger and SilberbauerGottsberger 1991). Floral scent trails for these insects, male and female alike, indicate specific micro-niches where they consistently find shelter, reliable food sources, and, most importantly, optimal mating opportunities (Gottsberger 1990; Gibernau et al. 1999). In Philodendron, the sterile (staminate) flowers, situated between the pistillate and the fertile staminate flowers, are known to undergo floral thermogenesis but also to provide nutritive floral tissue to the florivorous cyclocephaline scarabs during the female phase (Beath 1998; Gibernau et al. 1999, 2000; Gibernau and Barabé 2002; Seymour and Gibernau 2008; Pereira et al. 2014; Maldonado 
et al. 2015; Barbosa et al. 2019). In some Philodendron, the cyclocephaline scarabs were also observed to lick the abundant exudates from receptive stigmas (Gottsberger et al. 2013). In general, fertile staminate and pistillate flowers are not heavily damaged by the feeding activity, even during the male phase when temporarily resident cyclocephaline scarabs eat copious amounts of pollen (Gibernau et al. 1999; Gottsberger et al. 2013; Pereira et al. 2014; Maldonado et al. 2015; but see Gonçalves-Souza et al. 2018 for an exception). This feeding preference is explained by lower quantities of calcium oxalate crystals (e.g. an anti-herbivorous defence) in the upper portion (e.g. facing insects) of the sterile flowers than in pistillate or staminate flowers, resulting hence in better protection of fertile tissues (ovules and pollen grains) against the voracious cyclocephaline scarabs (Barabé et al. 2004; Coté and Gibernau 2012; Maldonado et al. 2015; Barbosa et al. 2018).

Although basic information about floral scent composition within cyclocephaline scarab beetle-pollinated taxa is still fragmentary, recent studies have shown that floral volatile organic compounds (VOCs) derived from several different biosynthetic metabolic pathways are implicated with the attraction of the insects. Among such compounds are (Z)-jasmone and 4vinylanisole (Dötterl et al. 2012), 4-methyl-5-vinylthiazole (Maia et al. 2012), (S)-2-hydroxy5-methylhexan-3-one (Maia et al. 2013), dihydro- $\beta$-ionone (Pereira et al. 2014), methyl 2methylbutanoate (Gottsberger et al. 2012), and 2-alkyl-3-methoxypyrazines (Maia et al. 2019). Either alone or in simple combinations with other constituents, these VOCs were selectively attractive to different species of cyclocephaline scarabs, suggesting an olfactory reproductive isolation of the corresponding angiosperms (Gibernau 2016; Pereira et al. 2014).

In this paper, we document key aspects of the pollination ecology of Philodendron fragrantissimum (Hook.) G.Don in French Guiana, identifying the effective pollinator(s) and quantifying the reproductive success of natural populations, whereas also assessing their spontaneous self-pollination capacity. We also provide a characterization of the floral scent 
chemistry through different headspace sampling methods. The specific questions were: i) is $P$. fragrantissimum pollinated by cyclocephaline scarab beetles?, ii) are its inflorescences thermogenic?, iii) is this species self-incompatible (e.g. obligatory cross-pollinated)?, and iv) is its floral scent dominated by a unique VOC or characterized by an original combination of VOCs?

\section{Material and Methods}

\section{Study site and focal species}

The study was conducted between January $17^{\text {th }}$ and $25^{\text {th }} 2012$ at the former Base-Vie camp Near the Petit Saut Dam, located between Sinnamary and Saint-Elie in French Guiana $\left(5^{\circ} 03^{\prime} \mathrm{N}\right.$, $\left.53^{\circ} 03^{\prime} \mathrm{W}\right)$. Monthly surveys were performed afterwards until May of the same year to check for fruit abortion or maturation. The investigated population consisted of ca. 50 mature individuals of $P$. fragrantissimum growing on large granite boulders or tree trunks in the forest understory (Figure 1A).

Philodendron fragrantissimum (Hooker) G. Don is a robust hemiepiphyte, forming rosettes at maturity. Petioles are green and fleshy, concave above and convex below (C-shaped in transversal cut), $30-70 \mathrm{~cm}$ long and ca. $2 \mathrm{~cm}$ in diameter. Leaf limbs are obovate-triangular, with a round or cordate base, green-coloured, $22-60 \mathrm{~cm}$ long and $10-40 \mathrm{~cm}$ wide. The inflorescence peduncle is pink, $5-8 \mathrm{~cm}$ long. The spathe is purplish-red at its base (below the constriction) and cream or light pinkish in its upper portion (Figures 1B-D). Its fleshy fruits (i.e. berries) are bright red when ripe (Figure 1E). This species is common in all the primary and secondary forests of French Guiana, except in the west and south of the territory (Barabé and Gibernau 2015). 


\section{Floral morphology}

Morphometric data were obtained from six inflorescences and include the total length of the spathe, as well as the spadix and its different floral zones (Figure 1C). Moreover, the number of pistillate flowers were counted in 12 inflorescences.

\section{Pollination biology}

The pollination of P. fragrantissimum was studied in January, during the short-lasting rainy season, when several individuals of this species were flowering. We recorded the number of inflorescences on 40 mature plants. The flowering sequence (e.g. anthesis) was observed on four inflorescences. Flower-visiting insects were surveyed in 15 inflorescences. When present they were collected, identified to species level and sexed.

\section{Reproductive success}

We labelled a total of 130 unmanipulated inflorescences of $P$. fragrantissimum to determine fruit set under natural conditions. To estimate the reproductive success rate of the studied population, the number of developing infructescences per individual plant was counted once a month until full maturation or abortion. The numbers of developed and aborted berries were also counted in 22 mature infructescences. Moreover, the number of developed seeds was counted in 19 berries, which were also measured and weighted. Spontaneous self-pollination was tested by bagging a total of 12 inflorescences in organdie bags before the opening of the spathe, preventing access to visiting insects.

The number of infructescences per plant was analysed with an ANOVA test according to the corresponding previous number of developed inflorescences, based on three flowering classes (low: 1-2; medium: 3-4; high: 5-9 developed inflorescences). The fruit set values in inflorescences in the open (unmanipulated) pollination and spontaneous self-pollination 
(bagged inflorescences) treatments were also statistically compared by a $\mathrm{Chi}^{2}$ test. Finally, the correlation between the number of seeds per berry and the size (length) of the berry was analysed with a linear model. All statistical tests were performed with Past 4.03 statistical software (Hammer et al., 2001).

\section{Floral thermogenesis}

We recorded temperatures of the spadix and the ambient air throughout anthesis with a data logging thermocouple thermometer (Digi-Sense ${ }^{\circledR}$ DualLogR, Cole-Parmer GmbH, Wertheim, Germany) every 10 min to determine floral heating patterns. To obtain the temperature of the spadix, one wire probe was inserted ca. $5 \mathrm{~mm}$ deep into the tissue in the middle of the fertile staminate zone. Data were recorded on three inflorescences from different individuals during the complete flowering sequence.

\section{Floral scent}

Floral scent samples were collected ex-situ from four inflorescences excised at the basis of the peduncle during the peak of thermogenic activity and floral scent emission on the female phase of anthesis. The inflorescences were enclosed within Nalophan (NA colourless, calibre 90, ETS Charles-Frères, Saint-Etienne, France) bags (opened in their upper part) to create a headspace. Sampling was conducted by two different methods on the same four inflorescences. In the first method, the emitted volatile organic compounds (VOCs) were adsorbed by Solid Phase Micro Extraction (SPME) Fibers (StableFlex ${ }^{\mathrm{TM}}$ SPME Fiber, $65 \mu \mathrm{m}$ PDMS-DVB Coating, Supelco, Darmstadt, Germany) for $20 \mathrm{~min}$, then stored at $5^{\circ} \mathrm{C}$ until analysis by thermal desorption. In the second method, by dynamic headspace, scented air was drawn for 30 min through adsorbent traps connected with silicone tubing to a membrane pump (ASF Thomas Inc, Memmingen, Germany) that worked at a constant flow of $250 \mathrm{~mL} \mathrm{~min}^{-1}$. The adsorbent traps (10 $\mathrm{cm}$ long, 
0.5 i.d.), made out of silanized glass cartridges, were filled with $50 \mathrm{mg}$ of a 1:1 mixture of Tenax $^{\text {TM }}$ TA (80/100, Macherey-Nagel 706318, Düren, Germany) and Carbopack ${ }^{\text {TM }}$ X (20/40, Supelco 1-0435), fixed in each tube with silanized glass wool plugs. After collection, the traps were eluted with $300 \mu \mathrm{L}$ of hexane (HPLC grade, bidistilled) and stored at $-24^{\circ} \mathrm{C}$ until analysis. To identify possible ambient contaminants, control samples were simultaneously collected from an empty bag to each scent sample, following the same protocols described above.

The trapped volatiles were analysed by combined gas chromatography-mass spectrometry (GC-MS). The SPME fibers were desorbed for $10 \mathrm{sec}$ at $250^{\circ} \mathrm{C}$ into the split/splitless injector of a gas chromatograph (Varian 450-GC, Varian BV, Middelburg, The Netherlands) equipped with a non-polar capillary column (VF-5ms, $30 \mathrm{~m}$ x $0.25 \mathrm{~mm}, 0.25 \mu \mathrm{m}$, Agilent Technologies, Santa Clara, USA) and coupled to an ion trap mass spectrometer (Varian 240-MS, Varian BV, Middelburg, The Netherlands). The temperature of the column was maintained at $50^{\circ} \mathrm{C}$ for $2 \mathrm{~min}$ after injection, linearly increased to $180^{\circ} \mathrm{C}$ at a rate of $5^{\circ} \mathrm{C} \mathrm{min}^{-1}$, and then increased to $250^{\circ} \mathrm{C}$ at a rate of $20^{\circ} \mathrm{C} \mathrm{min}^{-1}$ and maintained at $250^{\circ} \mathrm{C}$ for $1 \mathrm{~min}$. Solvent desorbed samples were analysed in an Agilent 5975C Series GC/MSD quadrupole system (Agilent Technologies, Santa Clara, USA), equipped with a non-polar column (HP-5ms, $30 \mathrm{~m}$ $\times 0.25 \mathrm{~mm}$ i.d., $0.25 \mu \mathrm{m}$ film thickness, Agilent Technologies, Santa Clara, USA). For each sample, a $1 \mu \mathrm{L}$ aliquot was injected in split mode (1:30) in a split/splitless injector. The GC temperature was set at $40^{\circ} \mathrm{C}$ for $2 \mathrm{~min}$, then increased at a rate of $4^{\circ} \mathrm{C} \min ^{-1}$ up to $230^{\circ} \mathrm{C}$ and held for 5 min. Helium was used as the carrier gas and maintained at a constant pressure of 7.0 psi. The MS interface was set at $230^{\circ} \mathrm{C}$ and the mass spectra recorded at $70 \mathrm{eV}$ (in EI mode) with a scan rate of 0.5 scan. $\mathrm{s}^{-1}$ of $m / z 40-350$. Compounds were identified by comparing their mass spectra and retention times to those of authentic standards available from the reference libraries Adams, MassFinder 4, NIST14 and Wiley Registry ${ }^{\mathrm{TM}}$ 9th Edition integrated into the Agilent MSD Productivity ChemStation software (Agilent Technologies, Palo Alto, USA). 
Peak areas in the chromatograms were integrated to obtain the total ionic signal and their values used to determine the relative proportions of each compound.

\section{Results}

\section{Floral morphology}

The inflorescences of $P$. fragrantissimum are composed of an $8-11 \mathrm{~cm}(9.6 \pm 0.9)$ white spadix and a $10-13 \mathrm{~cm}(11.7 \pm 1.3)$ spathe which is white-coloured above the constriction and reddish below. The spadix is composed of a zone of pistillate flowers (lower $2-2.6 \mathrm{~cm}, 2.3 \pm 0.3$, Figure 1C "Fe") within a floral chamber and another of staminate flowers (upper $5-7 \mathrm{~cm}, 6.1$ \pm 0.7 , Figure 1C "Ma"), separated by sterile staminate flowers $(0.9-1.5 \mathrm{~cm}, 1.1 \pm 0.2$, Figure $1 \mathrm{C}$ “St”).

We calculated the volume of the male zone, estimated as a cylinder, at $8.73 \pm 1.92 \mathrm{~cm}^{3}$. The average number of female flowers per inflorescence was $170.5 \pm 36.8$.

\section{Pollination biology}

Each individual bore one or several (up to 10) inflorescences at different stages of maturation, but only a single mature inflorescence was open at a time in each rosette. A total of 144 inflorescences were counted in the 40 marked individuals (average $3.6 \pm 2.1$ per plant). Philodendron fragrantissimum inflorescences were protogynous and exhibited a 2-day flowering sequence similar to that of other known congenerics (Gibernau et al., 2000; Maia et al., 2010). Throughout the morning of the first day of anthesis, the spathe slowly opens to expose the spadix while protecting the zone of pistillate flowers inside the floral chamber (Figure 1B). By late afternoon, the spathe was wide open (2/3 of the spathe length), the stigmas receptive (female phase) and the spadix felt warm to the touch. During the second day of the 
flowering sequence, the spathe slightly closed, and, in the afternoon, the male zone of the spadix begun to secrete droplets of a brownish and sticky resin (Figure 1D). At dusk, the spathe fully closed by folding around the spadix, from the base to the apex, and the anthers released pollen (male phase of anthesis). The inflorescences of $P$. fragrantissimum were exclusively visited and pollinated by a single species of cyclocephaline scarab, Cyclocephala simulatrix Höhne (Melolonthidae, Dynastinae, Cyclocephalini). During our monitoring for insect visitation, 15 inflorescences opened and in 11 of them (73\%), we observed at least one individual of $C$. simulatrix (mean $2.4 \pm 1.4$ beetles per inflorescence). The sex ratio of visiting $C$. simulatrix was roughly $1: 1(1.3 \pm 0.5 \% ; 1 \pm 0.1 \AA)$. The cyclocephaline scarabs mated within the floral chambers of $P$. fragrantissimum inflorescences, fed on the sterile staminate flowers (but also some fertile male flowers), and carried large loads of pollen stuck to their bodies by the spadix resinous exudate when leaving the inflorescence at the male phase of anthesis at dawn/early evening.

\section{Reproductive success}

Out of the 130 inflorescences labelled for the evaluation of natural pollination success, 71 infructescences were recorded (55\%), resulting in a mean of $1.8 \pm 1.4$ infructescences per plant. By the end of the survey, the berries from 39 infructescences were naturally removed, probably consumed by unknown frugivorous animals, leaving a "naked" rachis. Interestingly, the probability of fruit maturation was independent (ANOVA: $\mathrm{F}_{(2,36)}=0.09, \mathrm{p}=0.91$ ) of the number of developed inflorescences per plant (class groups : 1-2; 3-4; 5-9). No inflorescence bagged for the evaluation of self-pollination capacity developed into an infructescence. Hence the natural fruit set was significantly higher than that observed in the spontaneous self-pollination treatment $\left(\mathrm{Chi}^{2}: \chi^{2}{ }_{1}=6.36, \mathrm{p}=0.012\right)$. 
The natural pollination rate was very high (94\%) since fully ripe infructescences developed a mean of $152.7 \pm 35.3$ berries out of a total of $162.2 \pm 35.6$. The average mature berry was $0.93 \pm 0.16 \mathrm{~cm}$ long and $0.48 \pm 0.06 \mathrm{~cm}$ wide. The mean number of seeds per berry was $452 \pm 165$ (Figure 1E). The number of seeds per berry was positively correlated to berry size (i.e. length) (linear model: $\mathrm{R}^{2}=0.67, \mathrm{t}=5.88, \mathrm{p}<0.05$ ).

\section{Floral thermogenesis}

The two inflorescences monitored for floral thermogenesis exhibited remarkably similar spadix heating patterns and timing of events, despite being randomly chosen from different plants four days apart (Figure 2). There was one heating peak during each of the two consecutive evenings of the 2-day anthesis (Figure 2). Spadix temperatures peaked at $34 / 36.9^{\circ} \mathrm{C}(19 \mathrm{~h} 20 / 19 \mathrm{~h} 30)$ during the first evening when stigmas are receptive and pollinators are attracted by the emitted floral scent. This increase in temperature lasted until 22h40 / 23h30 (Figure 2A). The second temperature increase took place on the following evening when pollen is released. Spadix temperatures peaked at $30.2 / 30.6^{\circ} \mathrm{C}(18 \mathrm{~h} 00 / 19 \mathrm{~h} 00)$ about one hour earlier than in the female phase (previous evening). After 22h00, spadix temperatures decreased steadily to a level similar to that of the surrounding air as the spathe closed around the spadix (Figure 2.A). Between these two peaks, the two inflorescences presented different thermogenic "behaviours". In one inflorescence, spadix temperatures remained just above that of the surrounding air with the same trend, whereas the temperature of the second inflorescence increased between $02 \mathrm{~h} 00$ and $08 \mathrm{~h} 00$, reaching a maximum of $27.7^{\circ} \mathrm{C}$ at $04 \mathrm{~h} 40$ (Figure 2.A). When looking at the temperature differences, the spadices peaked at $11.2 / 12.9^{\circ} \mathrm{C}$ above the surrounding air during the first evening of anthesis, and at $6.7 / 7.6^{\circ} \mathrm{C}$ during the second night (Figure 2.B). Throughout the end of the first evening, the spadix of one inflorescence remained $\sim 1.5^{\circ} \mathrm{C}$ warmer than the 
surrounding air, whereas that of the other reached a temperature difference of $5.3^{\circ} \mathrm{C}$ at $04 \mathrm{~h} 50$. During the second day, the spadix was $\sim 2.5^{\circ} \mathrm{C}$ or $\sim 3.5^{\circ} \mathrm{C}$ warmer than ambient air.

\section{Floral scent}

During the female phase of anthesis, the spadix heat production was synchronized with the emission of volatile organic compounds (VOCs) perceived by the untrained human nose as a pleasant and intense white floral fragrance. The chemical analyses of the fragrant blend revealed a simple combination of 11 VOCs belonging to three different major biosynthetic pathways, namely: benzenoids/phenylpropanoids (6 VOCs), jasmone derivatives (4), and terpenoids (1). Three compounds alone - methyl benzoate, $(Z)$-jasmone, and dehydrojasmone - accounted for between 84 and $99.5 \%$ of the relative scent composition of $P$. fragrantissimum (Table 1). The two distinct headspace sampling methods yielded similar qualitative results, but substantial differences in the semi-quantitative results (e.g. relative amounts of each compound). Through dynamic headspace followed by desorption with hexane, the blend was largely dominated by methyl benzoate $(72 \pm 9 \%)$ and dehydrojasmone $(21 \pm 5 \%)$. On the other hand, the analyses of thermally desorbed SPME fibers with a PDMS-DVB resulted in a co-dominance of dehydrojasmone $(37 \pm 14 \%)$, $(Z)$-jasmone $(28 \pm 20 \%)$, and methyl benzoate $(25 \pm 9 \%)$. (Z)jasmone represented "only" $6 \pm 4 \%$ of the solvent desorbed samples, but was nevertheless still the third most abundant constituent in them. Another jasmone derivative, methyl jasmonate, was recovered in non-negligible amounts $(1.3 \pm 0.5 \%)$ in all SPME samples but was not detected in any of the solvent desorbed samples (Table 1). Several minor constituents were also exclusively identified in either of the two sampling methods (e.g. $\alpha$-copaene, benzyl acetate, benzyl benzoate).

\section{Discussion}


Our data show that Philodendron fragrantissimum, like all other congenerics, is likely pollinated by dusk/night-active cyclocephaline scarabs. It also exhibits the characteristic shortlasting anthesis $(\sim 30 \mathrm{~h})$ and traits such as floral thermogenesis, edible/nutritious floral tissues, and strong floral scents which are typically associated with flower-visiting cyclocephaline scarab beetles (Gottsberger and Amaral 1984; Gottsberger and Silberbauer-Gottsberger 1991; Gibernau et al. 1999, 2000; Gibernau and Barabé 2002; Maia et al. 2010; Gottsberger et al. 2013; Pereira et al. 2014; Gonçalves-Souza et al. 2017, 2018; Barbosa et al. 2019). In the studied natural population of $P$. fragrantissimum in French Guiana male and female individuals of Cyclocephala simulatrix Höhne were the only visitors observed inside anthetic inflorescences, suggesting a highly specialized pollination interaction. Our observations, however, were restricted to nine days. Cyclocephala simulatrix is a common and widespread species in French Guiana but also present in Venezuela, Brasil, Peru, Bolivia, and Paraguay (Dupuis and Perrin 2020). In French Guiana, adult individuals of $C$. simulatrix are active all year round, even though more abundant in March and June - December; interestingly, the lowest numbers of captures of this species occur in January, February, and April (Dupuis and Perrin 2020). The pollination ecology of other species of Philodendron growing in the same area was also documented, but these populations were in bloom in July. The inflorescences of $P$. melinonii Brongniart ex Regel were pollinated by $C$. colasi Endrödi (Gibernau et al. 2000), whereas those of $P$. squamiferum Poeppig by C. simulatrix (83\%) and C. tylifera Höhne (Gibernau and Barabé 2002). Four populations of P. solimoesense A.C.Smith, chiefly pollinated by C. colasi (99\%) in July (Gibernau et al. 1999), were also investigated in locations 19-23 km apart from the area where we conducted our study with $P$. fragrantissimum. The floral associations of $C$. simulatrix have only been documented in French Guiana (Moore and Jameson 2013). Hence, the species appears to be a seasonal specialized pollinator, associated with the inflorescences of $P$. fragrantissimum in January, and in July with those of P. squamiferum (Gibernau and Barabé 
2002) or P. solimoesense; only, for the latter, there are no detailed records available (Ponchel 2006 in Moore and Jameson 2013).

To our best knowledge, there is only one other report on the pollination of $P$. fragrantissimum from Barro Colorado Island in Panama (Beath 1998). The author reports inflorescences produced at the ends of ascending stems, between 2 - $15 \mathrm{~m}$ up in the lower forest canopy. At the end of the first day of anthesis, they emitted a sweet-spicy perfume and underwent thermogensis (up to $37^{\circ} \mathrm{C}$ ), being then visited by brown-colored Cyclocephala brevis Höhne (reported as C. sexpunctata Laporte, Moore and Jameson 2013) in numbers ranging from 1 - 4 individuals. Note that $C$. simulatrix is not reported from Panama (Ratcliffe 2003). It would thus appear that in these two natural populations (Panama and French Guiana), P. fragrantissimum is specifically pollinated by a single species of cyclocephaline scarab, which varies geographically. Although based on a fragmented data set, we could arguably assume that there is a functional replacement of pollinators. This subject must be approached with some restrain, as the floral scent chemistry of the 'Panamanian' population is unknown. Recently published data indicates that perfume chemotypes can vary significantly across different populations of cyclocephaline scarab-pollinated Xanthosoma striatipes (Kunth \& C.D. Bouché) Madison (Gottsberger et al. 2020). Moreover, at Barro Colorado Island, C. brevis is also documented as an effective pollinator of co-flowering Dieffenbachia longispatha Engler \& K. Krause, Xanthosoma helleborifolium (Jacq.) Schott, and X. mexicanum Liebmann (reported as X. pilosum K. Koch \& Augustin) (Beath 1998). Thus, both the geographical variation in floral scent chemotypes and pollinator host preferences should be assessed to draw further conclusions about these interactions.

The visitor exclusion experiments indicate that insect cross-pollination is obligatory for P. fragrantissimum. Hence, effectively attracting pollinating cyclocephaline scarabs is paramount for the plant's reproduction. Visual cues are likely secondary in the long-range 
attraction of pollinators at dusk and early evening hours (Gottsberger and SilberbauerGottsberger 1991). Hence, the conspicuous floral fragrance emitted by $P$. fragrantissimum inflorescences during the female phase of anthesis is likely to play a central role in luring both female and male $C$. simulatrix. Interestingly, the floral scent of $P$. fragrantissimum is dominated by only three dominant VOCs (i.e. methyl benzoate, (Z)-jasmone, and dehydrojasmone), and blends dominated by few volatile compounds appears to be characteristic of cyclocephaline scarab beetle-pollinated taxa (Gibernau et al. 2003; Maia et al. 2010, 2012, 2019; Pereira et al. 2014; Etl et al. 2016; Gonçalves-Souza et al. 2017; Milet-Pinheiro et al. 2017). Methyl benzoate is a ubiquitous floral VOC, previously documented in over 40 families of flowering plants. It is a major constituent in aroid genera associated with cyclocephaline scarab pollination (references), as well as drosophilid-pollinated Alocasia odora (Roxb.) K. Koch (24\%; Miyake et al. 2005) and bee-pollinated Anthurium armeniense Croat (5\%, Schwerdtfeger et al. 2002), Arum creticum Boissier \& Heldreich (9\%), and Ar. idaeum Cousturier \& Gandoger (1\%, Diaz and Kite 2006). On the other hand, (Z)-jasmone has only rarely been described in floral scents (10 families; Knudsen et al. 2006) but is remarkably well-documented in species belonging to different genera of cyclocephaline scarab-pollinated aroids, such as Caladium (Maia et al. 2012), Montrichardia (Gibernau et al. 2003), Philodendron (Dötterl et al. 2012; Gottsberger et al. 2013), and Xanthosoma (Milet-Pinheiro et al. 2017), as well as weevil-pollinated Cyclanthaceae (Ludovia lancifolia Brongniart, Teichert et al. 2018). Dehydrojasmone has only recently been analytically described (Maia et al. 2019) and appears to be unique to the floral scents of some night-blooming Neotropical Araceae.

Among cyclocephaline scarab-pollinated aroids, the combination of methyl benzoate and $(Z)$-jasmone in high relative amounts has been identified in the floral scents of several species of Xanthosoma (1 - 93\% and 0.1 - 67\% respectively, Milet-Pinheiro et al. 2017; Maia et al. 2019) and in Montrichardia arborescens (L.) Schott (1-4\% and 22-43\% respectively, 
Gibernau et al. 2003). The combination of ( $Z$ )-jasmone and dehydrojasmone is known from Xanthosoma riparium E.G. Gonçalves (91\% and 8\% respectively, Milet-Pinheiro et al. 2017), Xanthosoma striatipes (0.1-52\% and $17 \%$ respectively, Milet-Pinheiro et al. 2017), Dieffenbachia aurantiaca Engler (50\% and 30\% respectively, Etl et al. 2016), and P. mellobarretoanum R. Burle-Marx ex G.M. Barroso (60\% and 16-28\% respectively, Maia et al. 2019). Hence to our best knowledge, the triple combination of methyl benzoate, $(Z)$-jasmone and dehydrojasmone in significant proportions has not been yet reported, at least in Araceae (Gibernau et al. 2003; Maia et al. 2010, 2012, 2013, 2019; Dötterl et al. 2012; Gottsberger et al. 2013; Pereira et al. 2014). Consequently, the floral scent of Philodendron fragrantissimum appears to be original resulting from a unique combination of volatile compounds.

The two headspace sampling methods used to investigate the floral scent chemistry of P. fragrantissimum yielded similar qualitative results, although the relative proportions of compounds recovered in the GC-MS analyses were strongly differed. This could be attributed to affinity differences of the used adsorbent phases to specific compounds in the headspace (mostly based on polarity). But both the Tenax TA : Carbopack X mix used in the glass cartridges and the PDMS-DVB coating in the SPME fibers were selected for their affinity to floral VOCs. The other important difference is the sampling methods, one dynamic and the other static. Sampling of volatiles from a dynamic headspace eliminates some of the problems that are connected to sampling from static headspace (accumulation of certain compounds) and allow to collect, in general, larger amounts of volatiles by adsorption in a continuous air stream (Tholl et al. 2020).

Both female and male $C$. simulatrix were efficient in locating the scented inflorescences of $P$. fragrantissimum, with a visitation rate of almost $75 \%$. High visitation rates were also reported for other cyclocephaline scarab-pollinated, such as $P$. solimoesense (100\%, Gibernau et al. 1999) and P. acutatum Schott (>91.5\%, Maia et al. 2010), Caladium bicolor (Aiton) 
Ventenat (100\%, Maia and Schlindwein 2006), and Dieffenbachia nitidipetiolata Croat \& Grayum (reported as D. longispatha) (70\%, Young 1986). When pollinators are less abundant and/or the habitat is highly fragmented/disrupted, visitation rates can be lower as in the cases of Taccarum ulei Engler \& K. Krause (60\%, Maia et al. 2013), Montrichardia linifera (Arruda) Schott (58\%, Gibernau et al. 2003), or Xanthosoma daguense Engler (46\%, Garcia-Robledo et al. 2004). Pollinators associated with D. seguine (Jacq.) Schott in Los Tuxtlas (Mexico) were so rare that visitation rates did not exceed $5 \%$ (Cuartas-Hernandez 2006). The local abundance of pollinating cyclocephaline scarabs also varies throughout the years. Young (1990) reported visitation rates of up to $96 \%$ to the inflorescences of $D$. nitidipetiolata when pollinators were most abundant (average of 9 beetles per inflorescence); but the following year, the vistation rates dropped to ca. $70 \%$ when fewer pollinators were present (average of 3 beetles per inflorescence) (Young 1990).

The observed natural pollination success of $P$. fragrantissimum was relatively high since $55 \%$ of the inflorescences developed into mature infructescences. Moreover, C. simulatrix were very efficient pollinators since few individuals $(2-3)$ per inflorescence ensured the fertilization of almost $95 \%$ of the pistillate flowers, resulting in the maturation of a mean of 153 berries per infructescence or roughly 69,000 seeds. Similar rates of reproductive success were also reported for Montrichardia linifera (57\% infructescences, Gibernau et al. 2003), Dieffenbachia seguine (64\% infructescences and $85 \%$ berries, Gibernau 2015a); Dieffenbachia nitidipetiolata (reported as D. longispatha, 56\% infructescences and 48\% berries, Young 1986), and Xanthosoma daguense (52\% infructescences and 73\% berries, Garcia-Robledo et al. 2004). Under limiting pollination conditions of low plant density, reduced pollinator abundance, and/or habitat fragmentation, the reproductive success can be significantly lower, as in the cases of Dieffenbachia oerstedii Schott (19\% infructescences and 49\% berries, Valerio 1984) and Philodendron adamantinum Martius ex Schott (11\% infructescences in natural condition and 
$80 \%$ in hand-cross pollination, Pereira et al. 2014). By the end of our survey, 55\% infructescences presented a "naked" rachis, all the berries been naturally removed, probably by unknown frugivorous animals. Further studies are needed to better understand the outcomes of the seed set.

In conclusion, natural populations of Philodendron fragrantissimum in French Guiana were exclusively dependent on specialized pollination services of a single species cyclocephaline scarab, Cyclocephala simulatrix. The specific attraction of these pollinators is arguably attributed to the floral scent chemistry of their plant host, which is chiefly presented as an original combination of a benzenoid ester (methyl benzoate) and two jasmone derivatives ((Z)-jamone and dehydrojasmone).

\section{Acknowledgements}

We thank Aurélia Leguet for help in the field.

\section{Disclosure statement}

No potential conflict of interest was reported by the authors

\section{References}

Barabé, D, M Gibernau, F Forest. 2002. Zonal thermogenetic dynamics of two Philodendron species from two different subgenera (Araceae). Bot J Linn Soc. 139(1):79-86.

Barabé, D, C Lacroix, M Chouteau, M Gibernau. 2004. On the presence of extracellular calcium oxalate crystals on the inflorescences of Araceae. Bot J Linn Soc. 146(2):181-190.

Barabé, D., M Gibernau. 2015. Aracées de Guyane Française: Biologie et Systématique. Marseille: Publications scientifiques du Muséum, Paris ; IRD. 
Barbosa, JF, J Paulino, D Rodrigues, CM Sakuragi. 2018. Floral structure of Philodendron propinquum (Araceae) and a comparative study of the Philodendron subgenera. Flora 240:16.

Barbosa, JF, CM Sakuragui, D Rodrigues. 2019. Pollination of Philodendron propinquum Schott (Araceae): A new pattern in the lineage Philodendron. Int J Plant Sci. 180(2):153g159.

Beath, DN. 1998. Pollination Ecology of the Araceae - Central America. http://www.aroid.org/pollination/beath/index.php. Consulted on November $19^{\text {th }} 2020$.

Boyce, PC, TB Croat. 2020. The Überlist of Araceae, totals for published and estimated number of species in aroid genera. http://www.aroid.org/genera/20201008Uberlist.pdf. Accessed 12 November 2020.

Coté, GG, M Gibernau. 2012. Distribution of calcium oxalate crystals in floral organs of Araceae in relation to pollination strategy. Am J Bot. 99(7):1231-1242.

Cuartas-Hernandez, S. 2006. Efectos de la fragmentacion del bosque tropical: biologia reproductiva y sistema de apareamiento en poblaciones de Dieffenbachia seguine (Araceae). PhD thesis, Universidad Nacional Autonoma de Mexico, Mexico, 103p.

Diaz, A, GC Kite. 2006. Why be a rewarding trap? The evolution of floral rewards in Arum (Araceae), a genus characterized by saprophilous pollination systems. Biol J Linn Soc $88: 257-268$.

Dötterl, S, A David, W Boland, I Silberbauer-Gottsberger, G. Gottsberger. 2012. Evidence for behavioural attractiveness of methoxylated aromatics in a dynastid scarab beetle-pollinated Araceae. J Chem Ecol. 38(12):1539-1543.

Dupuis, F, R Perrin. 2020. Les Coléoptères Dynastidae de Guyane. Coleoptera, Sacrabaeoidea. Patrimoines naturels 81. Muséum national d'Histoire naturelle, Paris. 416p. 
Etl, F, A Berger, A Weber, J Schönenberger, S Dötterl. 2016. Nocturnal plant bugs use cisjasmone to locate inflorescences of an Araceae as feeding and mating site. J Chem Ecol. 42(4):300-304.

Garcia-Robledo, C, G Kattan, C Murcia, P Quintero-Marin. 2004. Beetle pollination and fruit predation of Xanthosoma daguense (Araceae) in an Andean cloud forest in Colombia. J Trop Ecol 20(July):459-469.

Gibernau, M. 2015a. Pollination ecology of two Dieffenbachia in French Guiana. Aroideana 38(EN2): 38-66.

Gibernau, M. 2015b. Floral Biology, Pollination Ecology \& Genetics of Dieffenbachia (Araceae) - a review. Aroideana 38:19-28

Gibernau, M. 2016. Pollinators and visitors of aroid inflorescences III - Phylogenetic \& Chemical insights. Aroideana - J Int Aroid Soc. 39(3):4-22.

Gibernau, M, D Barabé, P Cerdan, A Dejean. 1999. Beetle pollination of Philodendron solimoesense (Araceae) in French Guiana. Int J Plant Sci. 160(6):1135-1143.

Gibernau, M, D Barabé. 2000. Thermogenesis in three Philodendron species (Araceae) of French Guiana. Can J Bot. 78(5):685-689.

Gibernau, M, D Barabé, D Labat. 2000. Flowering and Pollination of Philodendron melinonii (Araceae) in French Guiana. Plant Biol. 2:330-333.

Gibernau, M, D Barabé. 2002. Pollination ecology of Philodendron squamiferum (Araceae). Can J Bot. 80(3):316-320.

Gibernau, M, D Barabé, D Labat, P Cerdan, A Dejean. 2003. Reproductive biology of Montrichardia arborescens (Araceae) in French Guiana. J Trop Ecol. 19(1):103-107.

Gibernau, M, D Barabé, M Moisson, A Trombe. 2005. Physical constraints on temperature difference in some thermogenic aroid inflorescences. Ann Bot. 96:117-125. 
Gonçalves, EG, ACD Maia. 2006. New evidence of pollination in Gearum brasiliense (Araceae - Spathicarpeae). Aroideana 29:148-151.

Gonçalves-Souza, P, C Schlindwein, S Dötterl, EAS Paiva. 2017. Unveiling the osmophores of Philodendron adamantinum (Araceae) as a means to understanding interactions with pollinators. Ann Bot. 119:533-543.

Gonçalves-Souza, P, C Schlindwein, EAS Paiva. 2018. Floral resins of Philodendron adamantinum (Araceae): secretion, release and synchrony with pollinators. Acta Bot Bras. 32(3):392-401

Gottsberger, G. 1990. Flowers and Beetles in the South American Tropics. Bot Acta. 103(4):360-365.

Gottsberger, G, A Amaral Jr. 1984. Pollination strategies in Brazilian Philodendron species. Ber Deustch Bot Ges. 97:391-410.

Gottsberger, G, I Silberbauer-Gottsberger. 1991. Olfactory and visual attraction of Erioscelis emarginata (Cyclocephalini, Dynastinae) to the inflorescences of Philodendron selloum (Araceae). Biotropica. 23(1):23-28.

Gottsberger, G, I Silberbauer-Gottsberger, RS Seymour, S Dötterl. 2012 Pollination ecology of Magnolia ovata may explain the overall large flower size of the genus. Flora. 207:107-118

Gottsberger, G, I Silberbauer-Gottsberger, S Dötterl. 2013. Pollination and floral scent differentiation in species of the Philodendron bipinnatifidum complex (Araceae). Plant Syst Evol. 299:793-809.

Gottsberger, G, I Silberbauer-Gottsberger, S Dötterl. 2020. Distant populations of a Xanthosoma (Araceae) species have different floral scents but the same cyclocephaline beetle pollinators. Acta Bot Bras. 34(3): 580-588.

Hammer, Ø, DAT Harper, PD Ryan. 2001. Past: Paleontological statistics software package for education and data analysis. Palaeontol Electron. 4: 9pp. 
Ito, K, RS Seymour. 2005. Expression of uncoupling protein and alternative oxidase depends on lipid or carbohydrate substrates in thermogenic plants. Biol Lett. 1:427-430.

Knudsen, JT, R Eriksson, J Gershenzon, B Ståhl. 2006. Diversity and distribution of floral scent. Bot. Rev. 72(1):1-120.

Maia, ACD, C Schlindwein. 2006. Caladium bicolor (Araceae) and Cyclocephala celata (Coleoptera, Dynastinae): a well-established pollination system in the Northern Atlantic rainforest of Pernambuco, Brazil. Plant Biol. 8:529-534.

Maia, ACD, C Schlindwein, DMAF Navarro, M Gibernau. 2010. Pollination of Philodendron acutatum (Araceae) in the atlantic forest of northeastern brazil: a single scarab beetle species guarantees high fruit set. Int J Plant Sci. 171(7):740-748.

Maia, ACD, S Dötterl, R Kaiser, I Silberbauer-Gottsberger, H Teichert, M Gibernau, DM do Amaral Ferraz Navarro, C Schlindwein, G Gottsberger. 2012. The key role of 4-methyl-5vinylthiazole in the attraction of scarab beetle pollinators: a unique olfactory floral signal shared by Annonaceae and Araceae. J Chem Ecol. 38(9):1072-1080.

Maia, ACD, M Gibernau, S Dötterl, DM do Amaral Ferraz Navarro, K Seifert, T Müller, C Schlindwein. 2013. The floral scent of Taccarum ulei (Araceae): attraction of scarab beetle pollinators to an unusual aliphatic acyloin. Phytochemistry. 93:71-78.

Maia, ACD, C Grimm, M Schubert, F Etl, EG Gonçalves, DMAF Navarro, S Schulz, S Dötterl. 2019. Novel Floral Scent Compounds from Night-Blooming Araceae Pollinated by Cyclocephaline Scarabs (Melolonthidae, Cyclocephalini). J Chem Ecol. 45:205-213.

Maldonado, M, CM Sakuragui, JR Trigo, D Rodrigues. 2015. The selective florivory of Erioscelis emarginata matches its role as a pollinator of Philodendron. Entomol Exp Appl. 156:290-300. 
Milet-Pinheiro, P, EG Gonçalves, DM do Amaral Ferraz Navarro, LA Nuñez-Avellaneda, ACD Maia. 2017. Floral scent chemistry and pollination in the Neotropical aroid genus Xanthosoma (Araceae). Flora 231: 1-10.

Miyake, T, M Yafuso. 2005. Pollination of Alocasia cucullata (Araceae) by two Colocasiomyia flies known to be specific pollinators for Alocasia odora. Plant Species Biol. 20:201-208.

Moore, MR, ML Jameson. 2013. Floral associations of cyclocephaline scarab beetles. J Insect Sci. 13(100):43.

Moore, MR, RD Cave, MA Branham. 2018. Synopsis of the cyclocephaline scarab beetles (Coleoptera, Scarabaeidae, Dynastinae). ZooKeys. 745:1-99.

Pereira, J, C Schlindwein, Y Antonini, ACD Maia, S Dötterl, C Martins, DMAF Navarro, R Oliveira. 2014. Philodendron adamantinum (Araceae) lures its single cyclocephaline scarab pollinator with specific dominant floral scent volatiles. Biol J Linn Soc. 111(3):679-691.

Ratcliffe, BC. 2003. The Dynastine scarab beetles of Costa Rica and Panama (Coleoptera: Scarabaeidae: Dynastinae). Bull. Univ. Nebraska State Museum 16: 1-506.

Schwerdtfeger, M, G Gerlach, R Kaiser. 2002. Anthecology in the Neotropical genus Anthurium (Araceae): a preliminary report. Selbyana 23(2):258-267.

Seymour, RS. 1999. Pattern of respiration by intact inflorescences of the thermogenic arum lily Philodendron selloum. J Exp Bot. 50(335):845-852.

Seymour, RS. 2010. Scaling of heat production by thermogenic flowers: limits to floral size and maximum rate of respiration. Plant Cell and Environ. 33:1474-1485.

Seymour, RS, M Gibernau. 2008. Respiration of thermogenic inflorescences of Philodendron melinonii: natural pattern and responses to experimental temperatures. J Exp Bot. 59:13531362. 
Seymour, RS, CR White, M Gibernau. 2009. Endothermy of dynastine scarab beetles (Cyclocephala colasi) associated with pollination biology of a thermogenic arum lily (Philodendron solimoesense). J Exp Biol. 212:2960-2968.

Teichert, H, S Dötterl, G Gottsberger. 2018. Scent emissions and floral nutrients of Carludovicoideae (Cyclanthaceae) and their importance for associated beetles Plant Syst Evol. 304(7):831-839.

Tholl, D, A Weinhold, USR Röse. 2020. Practical Approaches to Plant Volatile Collection and Analysis. In: Pichersky, E, N Dudareva. Biology of Plant Volatiles, $2^{\text {nd }}$ ed. CRC Press, Boca Raton (FL, USA): 3-26.

Valerio, CE. 1984. Insect visitors to the inflorescence of the aroid Dieffenbachia oerstedii (Araceae) in Costa Rica. Brenesia 22:139-148.

Young, HJ. 1986. Beetle pollination of Dieffenbachia longispatha (Araceae). Am J Bot. 73(6):931-944.

Young, HJ. 1990. Pollination and reproductive biology of an understory Neotropical aroid. In Reproductive ecology of tropical forest plants. KS Bawa and M Hadley eds. 17:151-164. 
Table 1. Average chemical composition (e.g. relative amounts of compounds) of the floral scent of Philodendron fragrantissimum from four inflorescences collected with two different sampling methods dynamic headspace and SPME fiber (see material and method). RI: Retention index.

\begin{tabular}{|c|c|c|c|c|c|}
\hline \multirow{3}{*}{$\mathbf{R I}$} & \multirow{3}{*}{$\begin{array}{c}\text { Compounds } \\
\text { Terpenoids (Sesquiterpenes) }\end{array}$} & \multirow{2}{*}{\multicolumn{2}{|c|}{$\begin{array}{c}\begin{array}{c}\text { Dynamic } \\
\text { headspace solvent } \\
\text { samples }\end{array} \\
\mathrm{n}=4\end{array}$}} & \multicolumn{2}{|c|}{$\begin{array}{l}\text { SPME fiber } \\
\text { samples }\end{array}$} \\
\hline & & & & \multicolumn{2}{|c|}{$\mathrm{n}=4$} \\
\hline & & Mean & SD & Mean & SD \\
\hline \multirow[t]{2}{*}{1377} & $\alpha$-Copaene & $0,02 *$ & 0.01 & --- & --- \\
\hline & \multicolumn{5}{|c|}{ Benzenoids and phenylpropanoids } \\
\hline 1033 & $\begin{array}{l}\text { Alcohols } \\
\text { Benzyl alcohol } \\
\text { Esters }\end{array}$ & 0.06 & 0.03 & 0.05 & 0.05 \\
\hline 1098 & Methyl benzoate & 71.72 & 8.70 & 24.77 & 8.48 \\
\hline 1170 & Benzyl acetate & --- & --- & 0.27 & 0.10 \\
\hline 1194 & Methyl salicylate & 0.13 & 0.05 & 1.04 & 0.43 \\
\hline \multirow[t]{2}{*}{1766} & Benzyl benzoate & --- & --- & 0.04 & 0.03 \\
\hline & Ethers & & & & \\
\hline \multirow[t]{2}{*}{1409} & 1,3,5-Trimethoxybenzene & $0,04 *$ & 0.04 & 0.11 & 0.09 \\
\hline & Jasmone derivatives & & & & \\
\hline 1305 & Dehydrojasmone & 21.27 & 5.17 & 37.28 & 14.18 \\
\hline 1409 & (Z)-jasmone & 6.31 & 4.43 & 27.49 & 19.60 \\
\hline 1650 & methyl jasmonate isomer 1 & --- & --- & 1.33 & 0.51 \\
\hline 1680 & methyl jasmonate isomer 2 & 0.29 & 0.13 & 7.71 & 2.94 \\
\hline
\end{tabular}


Figure 1. A. Philodendron fragrantissimum habitus, growing on a large granite boulder. B.

Flowering individual with two inflorescences: one receptive (left, spathe open) and the other already pollinated (right, spathe closed). C. Inflorescence in the female phase of anthesis (day 1) with the lower spathe cut-off, exposing the distinct floral zones of the spadix: pistillate $(\mathrm{Fe})$, sterile (St) and staminate (Ma). D. Inflorescence in the male phase of anthesis (day 2) with the release of resin droplets by the tissue in the male zone of the spadix before anther dehiscence.

E. Longitudinal (left) and transversal (right) sections of a mature berry containing hundreds of minute seeds.

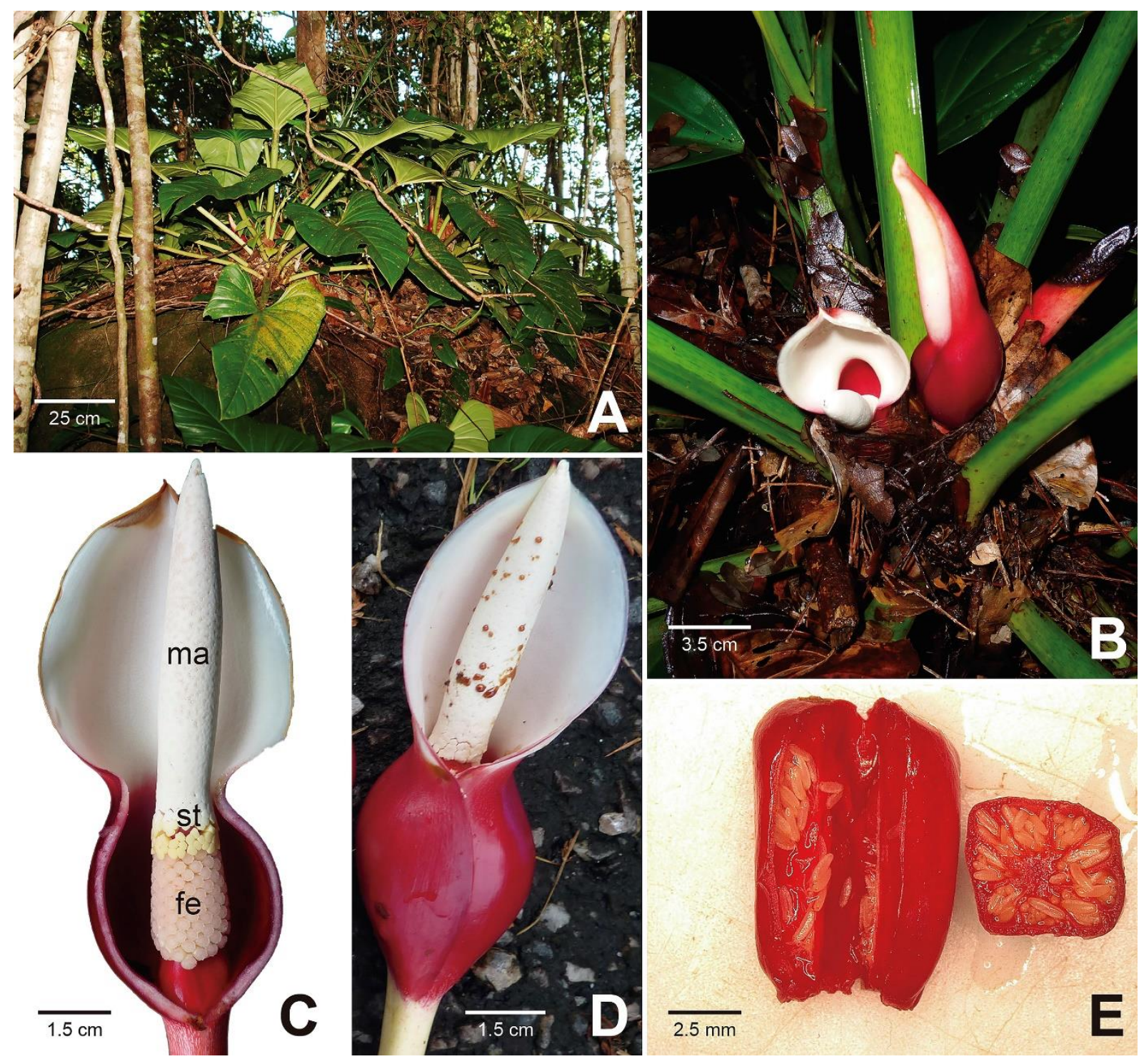


Figure 2. Floral thermogenesis in two inflorescences of Philodendron fragrantissimum. A. Temperature curves of the spadices (full lines) and surrounding air (dotted line) during the two consecutive days of anthesis. B. Differences of temperature between the spadices and surrounding air during the two days of anthesis. Spadix temperatures for the two different inflorescences were recorded on January 18 (black lines) and January 22 (grey lines).
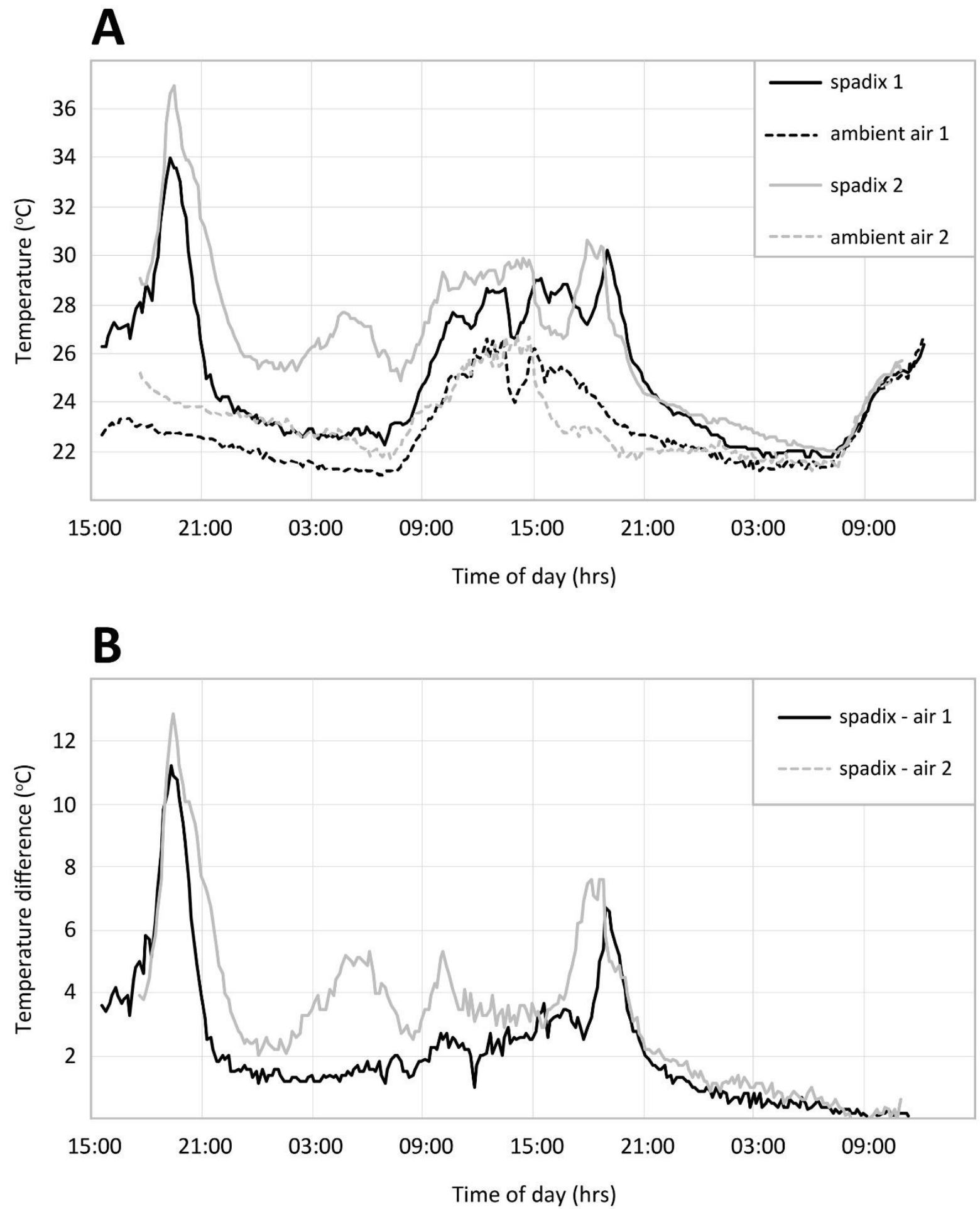